REVIEWS

UDC $577.22+578.76$

\title{
Relationship between TLR4 signalling alterations and effective human cytomegalovirus infection
}

\author{
D. Germini ${ }^{1,2}$, M. C. Arcangeletti ${ }^{2}$ \\ ${ }^{1}$ CNRS UMR 8126, Universit Paris-Sud 11, Institut Gustave Roussy \\ 114 , rue Edouard Vaillant, Villejuif, France, 94805 \\ ${ }^{2}$ Unit of Microbiology and Virology; Department of Clinical and Experimental Medicine; \\ University of Parma \\ via Antonio Gramsci 14, Parma, Italy, 43126 \\ germinidiego@gmail.com
}

\begin{abstract}
Toll-like receptors (TLR), the main class of immune-sensor molecules triggering the innate immunity pathways, are known to be involved in the infection of different RNA and DNA viruses, including herpesviruses. Human cytomegalovirus (HCMV) is a widespread human beta-herpesvirus that infects 80-90\% of the world's population and it can cause severe and even fatal diseases in immunocompromised patients and it is also responsible for birth defects as a consequence of congenital infection. Aim of this review is to discuss the existing data regarding the role of TLRs in HCMV concentrating mainly on TLR4. A better understanding in this relationship could be exploited for the development of efficient early diagnosis methodologies and anti viral therapies.
\end{abstract}

Keywords: human cytomegalovirus, Toll-like receptors, innate immune response.

Human cytomegalovirus. Human cytomegalovirus (HCMV) is a ubiquitous and widespread herpesvirus which infects the majority of the population during early childhood and establishes a lifelong relationship with its host as a latent virus [1]. Diseases can result from either primary infection or reactivation from latency. Although primary infection of healthy individuals is usually asymptomatic, it can cause birth defects following congenital infection or lead to severe and even fatal diseases in «at-risk» categories of individuals, such as transplant patients, HIV-infected subjects and patients with cancer [2-7].

Moreover HCMV has been associated also to other diseases such as tumors, atherosclerotic processes, cardiovascular pathologies and autoimmune diseases [4, $8-10]$. The association of HCMV to such a broad range of clinical features is supported by its ability to infect many cell types in vivo including different immune system effectors, such as myeloid progenitors, dendritic cells, monocytes and macrophages $[5,11-13]$. In parti-

(C) Institute of Molecular Biology and Genetics, NAS of Ukraine, 2014 cular the monocyte-macrophage system represents not only an important site of latency (monocytes) but also a way exploited by the virus to disseminate into host tissues (macrophages) [14,15]. Another striking characteristic of HCMV is its prominent capacity to counteract host defense mechanisms, mainly by interfering with intracellular signalling and inducing the transcription of cellular genes involved in the modulation of innate immunity, the inhibition of apoptosis and the cell cycle regulation [16-21]. A great number of cellular functions exploited by HCMV are often connected with the activation of Toll-Like Receptor (TLR)-mediated innate immunity. TLRs are the main class of immune-sensor molecules for the recognition of a broad range of pathogens. In particular, the TLR involvement in viral infections has been described both for DNA and RNA viruses [22-28]. Aim of this review is to provide useful information about the state of the art concerning the TLR involvement in HCMV infection focusing particular on TLR2 and TLR4.

An overview on Toll like receptors and HCMV infection. Toll-like receptors (TLRs) are transmemb- 
rane proteins that play a crucial role in the activation of the immune system. The recognition of pathogens associated molecular patterns (PAMPs) of specific pathogens activates the TLR mediated signalling cascade that transduces the signal to the nucleus provoking several effects, such as the NF- $\mathrm{KB}$ activation, the production of inflammatory cytokines, the maturation of dendritic cells, the enhancement of the production of co-stimulatory molecules involved in the immunitary response and the production of type I interferon $(\alpha, \beta, \gamma)[18,29$, 30]. The TLRs were firstly characterized for their ability to recognize bacterial components but nowadays it is well known their ability to interact also with viral and fungal molecules [31]. Concerning the TLRs involvement in HCMV infection the amount of data is still increasing but the first evidence that HCMV activates innate immunity in a TLR-dependent manner was obtained for TLR2 [18]. The stimulation of TLR2 by HCMV is replication-independent and results in the activation of NF- $\mathrm{KB}$ and the release of inflammatory cytokines without affecting the IFN pathway [32]. The direct demonstration that HCMV interacts with the dimer TLR2/ TLR1 was obtained firstly by Boheme and colleagues who demonstrated its interaction with the HCMV envelope glycoproteins $\mathrm{gB}$ and $\mathrm{gH}$ and the consequent NF$\kappa \mathrm{B}$ activation and cytokine secretion [22]. Chan and Guilbert have also demonstrated the significance of TRL2 in the immunopathogenesis of HCMV infection, reporting that UV-inactivated virions stimulate apoptosis in syncytiotrophoblast-like cells in a TLR2-dependent manner, likely contributing to chronic villitis and disruption of syncytiotrophoblasts, which often develop in placentas on delivery of newborns with congenital HCMV [33, 34].

Nowadays several studies are concentrating on the role played by TLR sequence single nucleotide polymorphism (SNPs) especially connected to the susceptibility to HCMV infection and the derived clinical sequelae. Data from studies conducted on other pathogens, such as rubella, measles and hepatitis B, suggest that SNPs in immune response genes may influence severity of infections and response to vaccinations [35-41]. So far, TLR gene polymorphisms were broadly investigated focusing on their effects on the immune response against various pathogens including hepatitis $\mathrm{C}$ virus (HCV), Legionella pneumophila, Plasmodium falcipa- rum, Mycobacterium leprae, Mycobacterium tuberculosis as well as HCMV [42-44]. Many studies also showed the involvement of different TLR SNPs in the course of inflammatory diseases and the altered expression of TLR-dependent immune response genes [45-48].

Concerning HCMV infection there are data supporting a connection between clinical evidences and TLR2 sequence - SNPs; in fact, in liver transplant recipients who carry the homozygous Arg753Gln mutation of TLR2, a higher incidence of HCMV-related disease was shown[49, 50]. This observation derived from clinical cases has been investigated by in vitro studies which showed that cells with the same mutation in TLR2 gene fail to recognize HCMV gB. This impaired viral recognition might prevent the development of a ro bust antiviral immune response, resulting in symptomatic disease in immunocompromised transplant recipients [51]. On the contrary, the heterozygosity for the TLR2 Arg677Trp SNP is significantly associated with a lower risk of HCMV infection in adults [52].

As described above there are several literature data demonstrating a direct involvement of TLR2 in the HCMV infection. Recently an increasing number of studies is focusing on the role of TLR4 in the HCMV infection and there is a big amount of data that describe its involvement at different stages. However, TLR4 does not seem directly involved in HCMV recognition, but its inhibition in THP-1 monocytic cell line-derived macrophages leads to a decreased rate of infection [53], while TLR4 ligands enhance the ability of dendritic cells to pre sent HCMV antigens leading to an increased number of both CD4- and CD8-positive antigen-specific activated $T$ cells [54].

TLR4 mediated response to HCMV. One of the first evidence of the potential involvement of TLR4 in HCMV infection was given in 2007 by Harwani and colleagues who evaluated the effect of bacterial lipopolysaccharide (LPS), the prototype TLR4 ligand, on HCMV replication in foreskin fibroblasts (HFF), a classical in vitro model of HCMV infection [55] and in ectocervical tissue explants, where HCMV replicates [56]. They demonstrated that treatment of HFF and ectocervical tissue explants with LPS significantly inhibits HCMV infection and that interferon beta (IFN $\beta$ ) contributes to this anti-HCMV effect [57]. This is an important proinflammatory cytokine that derives from the downstream 
signalling of TLR4 as well as IL-6 and IL-8 $[58,59]$. TLR4 signalling is activated after the recognition of a ligand which stimulates the engagement of two distinct TIR domain-containing adaptor proteins by the TLR4 conserved cytoplasmic domain: TIRAP (also known as Mal), which recruits MyD88 and TRAM (also called TICAM2 or TIRP), which in turn recruits TRIF [60]. The MyD88-TIRAP (MyD88 dependent) complex activates TRAF6 via IRAK kinases, whereas the TRAMTRIF (MyD88 independent) module recruits RIP1 or TRAF6 [58]. TLR4 is known to interact with two coreceptors (CD14 and MD-2) for the recognition of ligands. They stabilize the TLR4 expression on the cell surface following engagement of TLR4 with LPS and the TLR4/MD2/CD14 complex initiates and regulates additional downstream signalling via TRAF6 in a TIRAP dependent pathway, which in turn induces IL-6 and IL-8 [61-65]. Nevertheless, little is known about the mechanism by which the components of the TLR4/MD2/ CD14 complex mediate such effects in monocytes when TLR4 signalling is induced by HCMV. A study from Yew at al described that HCMV induces THP-1 cells (a monocytic cell line) signalling via this protein complex, suggesting that HCMV is able to activate TLR4 signalling and mediate cytokine induction [66]. Moreover they also showed that TRAM signalling was notable only with impaired TIRAP activity, thus possibly representing an «alternative» signalling route. This alternative pathway signalling also appears to increase activation of IFN-inducible genes via the TRAM-TRIF pathway, shifting from the canonical IL-6/IL-8 response to an IFN $\beta$ dominant response. They further observed that IL-6 induction by TLR4/MD2 is required for CD14 activation [66]. These pro-inflammatory cytokines themselves appear to play an important role in the pathogenesis of HCMV after bone marrow transplantation and can be useful predictors for HCMV infection and disease [67].

HCMV has also been demonstrated to be able to induce the transcription of several TLRs, and among them there is also TLR4 [53].

Beyond the classical function related to the innate immunity of the TLRs, TLR3, TLR4 and TLR5 have been described to have a function related to the regulation of the cell cycle $[68,69]$. HCMV is known to modify the cell cycle in different cell types [19, 70-75], however, only the inhibition of the TLR4 signalling pathway leads to a reduction of this effects in THP-1 monocytesderived macrophages [53] demonstrating that TLR4 is a mediator of HCMV-initiated cell cycle activation in THP-1 macrophages.

As already explained for TLR2, also polymorphisms in TLR4 gene have been reported to be associated with an altered immune response to pathogens. Arbour et al. discovered two polymorphisms in TLR4 gene, $1063 \mathrm{~A}>$ $\mathrm{G}$ and TLR4 $1363 \mathrm{C}>\mathrm{T}$, that result in amino acid substitutions, Asp299Gly and Thr399Ile, in the extracellular domain of the receptor with functional consequences [76]. In particular, these variants, lead to a blunted immunologic response to LPS and to a lower levels of proinflammatory cytokines production, acute phase reactants and soluble adhesion molecules [76, 77]. Moreover they have been reported to be associated with a higher susceptibility to infections caused by gram-negative bacteria [78, 79], Candida albicans [80], Brucella species [81], respiratory syncytial virus [82] and $P$. falciparum [83].

Clinical studies on renal transplant recipient patients determined that in patients heterozygous or homozygous for both of these polymorphisms or for only one of them there are not only more severe bacterial and opportunistic infections but also higher rates of HCMV diseases [24]. There are also other indirect proofs of the potential involvement of these polymorphisms in the HCMV infection. In fact, they were also studied for their role in the invasive aspergillosis (TLR4 is a receptor for Aspergillus species [84]) in allogenic hematopoietic-stem cell transplant patients [85]. It has been shown that they are related to an increased risk of invasive aspergillosis but no direct association in this respect was found: however, TLR4 SNPs were suggested to be associated with HCMV seropositivity, as the seropositivity for HCMV is another risk factor for invasive aspergillosis. Instead, interestingly, a more recent study showed that heterozygosity for the TLR4 Asp299Gly polymorphism was detected primarily in non-infected individuals and was associated with a lower level of viraemia and could be a protective factor for HCMV infection [52].

Conclusions. The knowledge of innate immunity response to HCMV is still incomplete but the number of data about this topic is continuously increasing. Indeed, it is well known that a better understanding of 
the molecular events driving HCMV infection and the host immune response mechanisms to this relevant pathogen could be fundamental for the development of efficient therapies, avoiding symptomatic reactivations from latency in «at risk» subjects.

In this respect the role of TLRs is being largely investigated as they are one of the main families of innate immunity receptors and very early «sentinels» to pathogen invasion. The proofs of their involvement in HCMV infection are increasing, especially for TLR2 and more recently, TLR4. At the present time, the data available show that they could be concurrently involved in the direct HCMV recognition, the derived intracellular signalling and the HCMV induced modulation of cellular metabolism (in particular, the alteration of the cell cycle).

A wider knowledge of TLR mediated response could be usefully exploited also to develop efficient screening methodologies and find reliable prognostic markers, especially in the case of HCMV congenital infections and transplant patients diseases. To this regard, the study of the role of TLR sequence SNPs seems very promising.

Взаємозв'язок між змінами TLR4 сигналінгу і ефективністю зараження цитомегаловірусом людини

Д. Жерміні, М. С. Аркангелетті

Резюме

Toll-подібні рецептори (TLR) як основний клас молекул імунних датчиків, щчо регулюють сигнальні шляхи вродженого імунітету, також беруть участь у зараженні різними РНК- $і$ ДНК-вірусами, з-поміж яких віруси герпесу. Цитомегаловірус людини - широко розповсюджений бета-герпесвірус людини, їм заражаено приблизно 80-90 \% населення земної кулі, шчо призводить до серйозних і навіть смертельних захворювань у пацієнтів з імунодефіцчитом та є причиною спадкових патологій через вроджені інфекuуї. Мета цуього огляду полягає в обговоренні існуючих даних щуодо ролі TLR, і особливо TLR4, в цитомегаловірусній інфекиї. Краще розуміння иього може бути використано для розробки ефективних методик ранньої діагностики і противірусних препаратів.

Ключові слова: ичитомегаловірус людини, Toll-подібні рецептори, вроджена імунна відповідь.

Взаимосвязь между изменениями TLR4 сигналинга и эффективностью заражения цитомегаловирусом человека

Д. Жермини, М. С. Аркангелетти

Резюме

Toll-подобные рецепторы (TLR) как основной класс молекул иммунных датчиков, регулирующих сигнальнье пути врожденного иммунитета, участвуют также в заражении различными РНКи ДНК-вирусами, включая вирусы герпеса. Цитомегаловирус человека - широко распространенный бета-герпесвирус человека, им заражаено примерно 80-90\% населения земного шара, что приводит к серьезным и даже смертельным заболеваниям у пациентов с иммунодефицитом и является причиной наследственных патологий из-за врожденной инфекиии. Цель представленного обзора состоит в обсуждении сущеествуюших данных о роли TLR, $u$ особенно TLR4, в цитомегаловирусной инфекичи. Лучшее понимание этого может быть использовано для разработки эффективных методик ранней диагностики и противовирусных препаратов.

Ключевые слова: ичтомегаловирус человека, Toll-подобные рецепторы, врожденный иммунный ответ.

\section{REFERENCES}

1. Mocarski ES, Courcelle CT. Cytomegalovirus and their replication. Fields Virology. Philadelphia, 2001; 2629-73.

2. Alford CA, Britt WJ. Cytomegalovirus. Fields Virology. Philadelphia, 1996; 2493-534.

3. Bosch W, Heckman MG, Diehl NN, Set al. Association of cytomegalovirus infection and disease with death and graft loss after liver transplant in high-risk recipients. Am J Transplant. 2011; 11(10):2181-9.

4. Cobbs CS, Harkins L, Samanta M, et al. Human cytomegalovirus infection and expression in human malignant glioma. Cancer Res. 2002;62(12):3347-50.

5. Pass RF. Cytomegalovirus. Fields Virology. Philadelphia, 2001; 2575-705.

6. Ramsay ME, Miller E, Peckham CS. Outcome of confirmed symptomatic congenital cytomegalovirus infection. Arch Dis Child. 1991;66(9):1068-9.

7. Razonable RR, Paya $C V$. Herpesvirus infections in transplant recipients: current challenges in the clinical management of cytomegalovirus and Epstein-Barr virus infections. Herpes. 2003; 10(3):60-5.

8. Lunardi C, Bason C, Corrocher R, Puccetti A. Induction of endothelial cell damage by hCMV molecular mimicry. Trends Immunol. 2005;26(1):19-24.

9. Soderberg-Naucler C, Streblow DN, Fish KN, et al. Reactivation of latent human cytomegalovirus in CD14(+) monocytes is differentiation dependent. J Virol. 2001;75(16):7543-54.

10. Varani $S$, Landini MP. Cytomegalovirus-induced immunopathology and its clinical consequences. Herpesviridae. 2011;2(1):6.

11. Arrode $G$, Davrinche $C$. Dendritic cells and HCMV cross-presentation. Curr Top Microbiol Immunol. 2003;276:277-94.

12. Rolle A, Olweus J. Dendritic cells in cytomegalovirus infection: viral evasion and host countermeasures. APMIS. 2009;117(56):413-26.

13. Slobedman B, Stern JL, Cunningham AL, et al. Impact of human cytomegalovirus latent infection on myeloid progenitor cell gene expression. J Virol. 2004;78(8):4054-62.

14. Ioudinkova E, Arcangeletti MC, Rynditch A, et al. Control of human cytomegalovirus gene expression by differential histone modifications during lytic and latent infection of a monocytic cell line. Gene. 2006;384:120-8.

15. Smith MS, Bentz GL, Alexander JS, Yurochko AD. Human cytomegalovirus induces monocyte differentiation and migration as a strategy for dissemination and persistence. J Virol. 2004;78(9): 4444-53.

16. Billstrom Schroeder M, Christensen R, Worthen GS. Human cytomegalovirus protects endothelial cells from apoptosis induced 
by growth factor withdrawal. J Clin Virol. 2002;25 Suppl 2: S149-57.

17. Castillo JP, Kowalik TF. HCMV infection: modulating the cell cycle and cell death. Int Rev Immunol. 2004;23(1-2):113-39.

18. Compton T, Kurt-Jones EA, Boehme KW, et al. Human cytomegalovirus activates inflammatory cytokine responses via CD14 and Toll-like receptor 2. J Virol. 2003;77(8):4588-96.

19. Hertel L, Mocarski ES. Global analysis of host cell gene expression late during cytomegalovirus infection reveals extensive dysregulation of cell cycle gene expression and induction of Pseudomitosis independent of US28 function. J Virol. 2004;78(21): 11988-2011.

20. Salsman J, Jagannathan M, Paladino P, et al. Proteomic profiling of the human cytomegalovirus UL35 gene products reveals a role for UL35 in the DNA repair response. J Virol. 2012;86(2):806-20.

21. Wolf J, Weinberger B, Grubeck-Loebenstein B. The immunoregulatory effects of CMV-infection in human fibroblasts and the impact on cellular senescence. Immun Ageing. 2012;9:1.

22. Boehme KW, Guerrero M, Compton T. Human cytomegalovirus envelope glycoproteins $\mathrm{B}$ and $\mathrm{H}$ are necessary for TLR2 activation in permissive cells. J Immunol. 2006;177(10):7094-102.

23. Cai MS, Li ML, Zheng CF. Herpesviral infection and Toll-like receptor 2. Protein Cell. 2012;3(8):590-601.

24. Ducloux D, Deschamps M, Yannaraki M, et al. Relevance of Tolllike receptor-4 polymorphisms in renal transplantation. Kidney Int. 2005;67(6):2454-61.

25. Gaur P, Munjhal A, Lal SK. Influenza virus and cell signaling pathways. Med Sci Monit. 2011;17(6):RA148-54.

26. Kurt-Jones EA, Chan $M$, Zhou $S$, et al. Herpes simplex virus 1 interaction with Toll-like receptor 2 contributes to lethal encephalitis. Proc Natl Acad Sci U S A. 2004;101(5):1315-20.

27. Lofgren J, Marttila R, Renko M, Ramet M, Hallman M. Toll-like receptor 4 Asp299Gly polymorphism in respiratory syncytial virus epidemics. Pediatr Pulmonol. 2010;45(7):687-92.

28. Xagorari A, Chlichlia K. Toll-like receptors and viruses: induction of innate antiviral immune responses. Open Microbiol J. 2008; 2:49-59.

29. Malmgaard L, Melchjorsen J, Bowie AG, et al. Viral activation of macrophages through TLR-dependent and -independent pathways. J Immunol. 2004;173(11):6890-8.

30. Remer KA, Brcic M, Sauter KS, Jungi TW. Human monocytoid cells as a model to study Toll-like receptor-mediated activation. J Immunol Methods. 2006;313(1-2):1-10.

31. van der Kleij D, van den Biggelaar AH, Kruize YC, et al. Responses to Toll-like receptor ligands in children living in areas where schistosome infections are endemic. J Infect Dis. 2004;189(6): 1044-51.

32. Juckem LK, Boehme KW, Feire AL, Compton T. Differential initiation of innate immune responses induced by human cytomegalovirus entry into fibroblast cells. J Immunol. 2008;180(7): 4965-77.

33. Chan G, Guilbert LJ. Ultraviolet-inactivated human cytomegalovirus induces placental syncytiotrophoblast apoptosis in a Tolllike receptor-2 and tumour necrosis factor-alpha dependent manner. J Pathol. 2006;210(1):111-20.

34. Rossini $G$, Cerboni $C$, Santoni A, et al. Interplay between human cytomegalovirus and intrinsic/innate host responses: a complex bidirectional relationship. Mediators Inflamm. 2012;2012:607276.

35. Bieback K, Lien E, Klagge IM, et al. Hemagglutinin protein of wild-type measles virus activates toll-like receptor 2 signaling. $J$ Virol. 2002;76(17):8729-36.

36. Desombere I, Hauser P, Rossau R, et al. Nonresponders to hepatitis B vaccine can present envelope particles to T lymphocytes. $J$ Immunol. 1995;154(2):520-9.
37. Hohler T, Reuss E, Evers N, et al. Differential genetic determination of immune responsiveness to hepatitis B surface antigen and to hepatitis A virus: a vaccination study in twins. Lancet. 2002; 360(9338):991-5.

38. Kurt-Jones EA, Popova L, Kwinn L, et al. Pattern recognition receptors TLR 4 and CD14 mediate response to respiratory syncytial virus. Nat Immunol. 2000;1(5):398-401.

39. Pankratz VS, Vierkant RA, O'Byrne MM, et al. Associations between SNPs in candidate immune-relevant genes and rubella antibody levels: a multigenic assessment. BMC Immunol. 2010; 11:48.

40. Poland $G A$. Variability in immune response to pathogens: using measles vaccine to probe immunogenetic determinants of response. Am J Hum Genet. 1998;62(2):215-20.

41. Wang C, Tang J, Song $W$, et al. HLA and cytokine gene polymorphisms are independently associated with responses to hepatitis B vaccination. Hepatology. 2004;39(4):978-88.

42. Netea $M G$, Wijmenga C, O'Neill LA. Genetic variation in Toll-like receptors and disease susceptibility. Nat Immunol. 2012;13(6): $535-42$.

43. Texereau J, Chiche JD, Taylor W, et al. The importance of Tolllike receptor 2 polymorphisms in severe infections. Clin Infect Dis. 2005;41 Suppl 7:S408-15.

44. Wang JJ, Xia X, Tang SD, et al. Meta-analysis on the associations of TLR2 gene polymorphisms with pulmonary tuberculosis susceptibility among Asian populations. PLoS One. 2013;8(10): e75090.

45. Ahmad-Nejad P, Mrabet-Dahbi S, Breuer K, et al. The toll-like receptor $2 \mathrm{R} 753 \mathrm{Q}$ polymorphism defines a subgroup of patients with atopic dermatitis having severe phenotype. J Allergy Clin Immunol. 2004;113(3):565-7.

46. Kormann MS, Ferstl R, Depner $M$, et al. Rare TLR2 mutations reduce TLR2 receptor function and can increase atopy risk. $\mathrm{Al}$ lergy. 2009;64(4):636-42.

47. Lazarus R, Klimecki WT, Raby BA, et al. Single-nucleotide polymorphisms in the Toll-like receptor 9 gene (TLR9): frequencies, pairwise linkage disequilibrium, and haplotypes in three U.S. ethnic groups and exploratory case-control disease association studies. Genomics. 2003;81(1):85-91.

48. Nahum A, Dadi H, Bates A, Roifman CM. The biological significance of TLR3 variant, L412F, in conferring susceptibility to cutaneous candidiasis, CMV and autoimmunity. Autoimmun Rev. 2012;11(5):341-7.

49. Kang SH, Abdel-Massih RC, Brown RA, et al. Homozygosity for the toll-like receptor $2 \mathrm{R} 753 \mathrm{Q}$ single-nucleotide polymorphism is a risk factor for cytomegalovirus disease after liver transplantation. J Infect Dis. 2012;205(4):639-46.

50. Kijpittayarit S, Eid AJ, Brown RA, et al. Relationship between Toll-like receptor 2 polymorphism and cytomegalovirus disease after liver transplantation. Clin Infect Dis. 2007;44(10):1315-20.

51. Brown RA, Gralewski JH, Razonable RR. The R753Q polymorphism abrogates toll-like receptor 2 signaling in response to human cytomegalovirus. Clin Infect Dis. 2009;49(9):e96-9.

52. Jablonska A, Paradowska E, Studzinska M, et al. Relationship between toll-like receptor 2 Arg677Trp and Arg753Gln and tolllike receptor 4 Asp299Gly polymorphisms and cytomegalovirus infection. Int J Infect Dis. 2014;25:11-5.

53. Arcangeletti MC, Germini D, Rodighiero I, et al. Toll-like receptor 4 is involved in the cell cycle modulation and required for effective human cytomegalovirus infection in THP-1 macrophages. Virology. 2013;440(1):19-30.

54. Lore K, Betts MR, Brenchley JM, et al. Toll-like receptor ligands modulate dendritic cells to augment cytomegalovirus- and HIV1-specific T cell responses. J Immunol. 2003;171(8):4320-8. 
55. Isomura H, Stinski MF. The human cytomegalovirus major immediate-early enhancer determines the efficiency of immediateearly gene transcription and viral replication in permissive cells at low multiplicity of infection. J Virol. 2003;77(6):3602-14.

56. Fox-Canale AM, Hope TJ, Martinson J, et al. Human cytomegalovirus and human immunodeficiency virus type-1 co-infection in human cervical tissue. Virology. 2007;369(1):55-68.

57. Harwani SC, Lurain NS, Zariffard MR, Spear GT. Differential inhibition of human cytomegalovirus (HCMV) by toll-like receptor ligands mediated by interferon-beta in human foreskin fibroblasts and cervical tissue. Virol J. 2007;4:133.

58. Fitzgerald KA, Chen ZJ. Sorting out Toll signals. Cell. 2006;125 (5):834-6.

59. Xie XH, Law HK, Wang LJ, et al. Lipopolysaccharide induces IL-6 production in respiratory syncytial virus-infected airway epithelial cells through the toll-like receptor 4 signaling pathway. Pediatr Res. 2009;65(2):156-62.

60. Watts $C$. Location, location, location: identifying the neighborhoods of LPS signaling. Nat Immunol. 2008;9(4):343-5.

61. Akashi S, Saitoh S, Wakabayashi Y, et al. Lipopolysaccharide interaction with cell surface Toll-like receptor 4-MD-2: higher affinity than that with MD-2 or CD14. J Exp Med. 2003;198 (7):1035-42.

62. Kennedy MN, Mullen GE, Leifer CA, et al. A complex of soluble MD-2 and lipopolysaccharide serves as an activating ligand for Toll-like receptor 4. J Biol Chem. 2004;279(33):34698-704.

63. Sacre SM, Lundberg AM, Andreakos E, et al. Selective use of TRAM in lipopolysaccharide (LPS) and lipoteichoic acid (LTA) induced NF-kappaB activation and cytokine production in primary human cells: TRAM is an adaptor for LPS and LTA signaling. J Immunol. 2007;178(4):2148-54.

64. Tanimura $N$, Saitoh S, Matsumoto $F$, Akashi-Takamura S, Miyake $K$. Roles for LPS-dependent interaction and relocation of TLR4 and TRAM in TRIF-signaling. Biochem Biophys Res Commun. 2008;368(1):94-9.

65. Yamamoto $M$, Sato $S$, Hemmi $H$, et al. TRAM is specifically involved in the Toll-like receptor 4-mediated MyD88-independent signaling pathway. Nat Immunol. 2003;4(11):1144-50.

66. Yew KH, Carpenter C, Duncan RS, Harrison CJ. Human cytomegalovirus induces TLR4 signaling components in monocytes altering TIRAP, TRAM and downstream interferon-beta and TNF-alpha expression. PLoS One. 2012;7(9):e44500.

67. Humar A, St Louis P, Mazzulli T, et al. Elevated serum cytokines are associated with cytomegalovirus infection and disease in bone marrow transplant recipients. J Infect Dis. 1999;179(2):484-8.

68. Hasan UA, Trinchieri $G$, Vlach J. Toll-like receptor signaling stimulates cell cycle entry and progression in fibroblasts. $J$ Biol Chem. 2005;280(21):20620-7.

69. Hasan UA, Caux C, Perrot I, et al. Cell proliferation and survival induced by Toll-like receptors is antagonized by type I IFNs. Proc Natl Acad Sci U S A. 2007;104(19):8047-52.

70. Arcangeletti MC, Rodighiero I, Mirandola P, et al. Cell-cycledependent localization of human cytomegalovirus UL83 phosphoprotein in the nucleolus and modulation of viral gene expres- sion in human embryo fibroblasts in vitro. J Cell Biochem. 2011;112(1):307-17.

71. Bain M, Sinclair J. The S phase of the cell cycle and its perturbation by human cytomegalovirus. Rev Med Virol. 2007;17(6): 423-34.

72. Fortunato EA, Sanchez V, Yen JY, Spector DH. Infection of cells with human cytomegalovirus during $\mathrm{S}$ phase results in a blockade to immediate-early gene expression that can be overcome by inhibition of the proteasome. J Virol. 2002;76(11):5369-79.

73. Sinclair J, Baillie J, Bryant L, Caswell R. Human cytomegalovirus mediates cell cycle progression through $\mathrm{G}(1)$ into early $\mathrm{S}$ phase in terminally differentiated cells. J Gen Virol. 2000;81(Pt 6):1553-65.

74. Song YJ, Stinski MF. Inhibition of cell division by the human cytomegalovirus IE86 protein: role of the p53 pathway or cyclindependent kinase 1/cyclin B1. J Virol. 2005;79(4):2597-603.

75. Wiebusch L, Asmar J, Uecker R, Hagemeier C. Human cytomegalovirus immediate-early protein 2 (IE2)-mediated activation of cyclin $\mathrm{E}$ is cell-cycle-independent and forces S-phase entry in IE2-arrested cells. J Gen Virol. 2003;84(Pt 1):51-60.

76. Arbour NC, Lorenz E, Schutte BC, et al. TLR4 mutations are associated with endotoxin hyporesponsiveness in humans. Nat Genet. 2000;25(2):187-91.

77. Kiechl S, Lorenz E, Reindl M, et al. Toll-like receptor 4 polymorphisms and atherogenesis. N Engl J Med. 2002;347(3):185-92.

78. Agnese DM, Calvano JE, Hahm SJ, et al. Human toll-like receptor 4 mutations but not CD14 polymorphisms are associated with an increased risk of gram-negative infections. J Infect Dis. 2002;186(10):1522-5.

79. Lorenz E, Mira JP, Frees KL, Schwartz DA. Relevance of mutations in the TLR4 receptor in patients with gram-negative septic shock. Arch Intern Med. 2002;162(9):1028-32.

80. Van der Graaf CA, Netea MG, Morre SA, et al. Toll-like receptor 4 Asp299Gly/Thr399Ile polymorphisms are a risk factor for Candida bloodstream infection. Eur Cytokine Netw. 2006;17(1): 29-34.

81. Rezazadeh $M$, Hajilooi $M$, Rafiei A, et al. TLR4 polymorphism in Iranian patients with brucellosis. J Infect. 2006;53(3):206-10.

82. Tal G, Mandelberg A, Dalal I, et al. Association between common Toll-like receptor 4 mutations and severe respiratory syncytial virus disease. J Infect Dis. 2004;189(11):2057-63.

83. Mockenhaupt FP, Cramer JP, Hamann L, et al. Toll-like receptor (TLR) polymorphisms in African children: Common TLR-4 variants predispose to severe malaria. Proc Natl Acad Sci US A. 2006;103(1): 177-82.

84. Netea MG, Warris A, Van der Meer JW, et al. Aspergillus fumigatus evades immune recognition during germination through loss of toll-like receptor-4-mediated signal transduction. J Infect Dis. 2003;188(2):320-6.

85. Bochud PY, Chien JW, Marr KA, et al. Toll-like receptor 4 polymorphisms and aspergillosis in stem-cell transplantation. $N$ Engl J Med. 2008;359(17):1766-77. 